Technological University Dublin

DÜBLIN

ARROW@TU Dublin

Articles

Dublin Energy Lab

2017

\title{
Characteristics of Different Systems for the Solar Drying of Crops
}

Brian Norton

Technological University Dublin, brian.norton@tudublin.ie

Follow this and additional works at: https://arrow.tudublin.ie/dubenart

Part of the Engineering Commons

\section{Recommended Citation}

Norton, B. (2017). Characteristics of different systems for the solar drying of crops. In Prakash and Kumar (eds.), Solar Drying Technology Springer. doi:10.1007/978-981-10-3833-4

This Article is brought to you for free and open access by the Dublin Energy Lab at ARROW@TU Dublin. It has been accepted for inclusion in Articles by an authorized administrator of ARROW@TU Dublin. For more information, please contact arrow.admin@tudublin.ie, aisling.coyne@tudublin.ie,gerard.connolly@tudublin.ie.

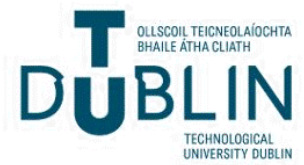




\title{
Characteristics of Different Systems for the Solar Drying of Crops
}

\author{
Brian Norton \\ Dublin Energy Lab, Dublin Institute of Technology \\ Grangegorman, Dublin 7, Ireland \\ Corresponding Author: president@dit.ie (Brian Norton)
}

\begin{abstract}
Solar dryers are used to enable the preservation of agricultural crops, food processing industries for dehydration of fruits and vegetables, fish and meat drying, dairy industries for production of milk powder, seasoning of wood and timber, textile industries for drying of textile materials. The fundamental concepts and contexts of their use to dry crops is discussed in the chapter. It is shown that solar drying is the outcome of complex interactions particular between the intensity and duration of solar energy, the prevailing ambient relative humidity and temperature, the characteristics of the particular crop and its pre-preparation and the design and operation of the solar dryer.
\end{abstract}

\section{Keywords:}

Solar drying; Psychometry, Moisture content; Post-harvest technology 


\section{Introduction}

\section{Drying agricultural crops enables}

- Lower post-harvest crop losses

- Production of high quality food Products

- Long-term storage without deterioration

- Securing higher prices for crops at times after harvest

- Planning of early harvests

- Maintenance of seed availability

Traditional open-sun drying has, since ancient times, been accomplished by simply placing the crop outdoors, often on a prepared surface or mat, to receive insolation. This causes the crop to heat-up and release moisture to the warm relatively-dry adjacent air (Jain and Tiwari, 2003). Open-sun drying remains widely used for postharvest crop preservation in locations where appropriately sunny and dry conditions prevail with predictable reliably very soon after the crop has been harvested. If a sufficiently large land area is readily available then open-sun drying can be used to dry single, or very shallow, crop depths without further capital investment. Open-sun drying entails limited specialist expertise, though some skill is required to optimally cut a crop into pieces whose size and shape meet consumer expectations whist also achieving reasonably rapid drying. Open-sun drying can be labour intensive as, in addition to crop preparation, the crop usually must be turned and, if it rains, moved to storage. Open-sun drying also is prone to contamination and damage by birds, rats and insects. Open-sun drying can proceed slowly and intermittently with the crop finally being over-dried or, more commonly, under-dried to a relatively high final moisture content. As there is no protection from rain or dew, the crop can suffer mould growth during drying.

The key strategic drivers to the greater use of solar energy in crop processing are (i) global greenhouse gas emissions (Kumar and Kandpal, 2005) (ii) local pollution caused by the use of fossil fuels, (iii) the desire for security of energy supply energy and (iv) certainly of life-cycle system costs. By providing a contained drying environment in which air has been heated by between $10-30^{\circ} \mathrm{C}$ above ambient temperature, solar dryers dry a crop more rapidly than an open-sun dryer. This faster drying (i) improves dried crop quality, (ii) enables a higher crop throughput and (iii) the drying area required is thus much smaller than open-sun drying. However careful design and operation is required to avoid drying a crop too rapidly as case hardening with subsequent internal mould growth may ensue. Solar dryers also protect foods from dust, insects, birds and animals. They can be constructed from locally available materials at a relatively low capital cost and there are usually no fuel costs.

The key objectives of drying crops are to remove moisture as quickly as possible at a temperature that does not seriously affect the flavour, texture and colour of the ensuing food product. If the drying temperature is maintained too low, microorganisms may grow before the moist conditions for their development have reduced to the safe storage moisture content. After drying for a specific range of temperature for a particular crop moisture content must be maintained within specified limits to minimize deterioration. 
Temperatures from $-37 \mathrm{C}$ to $71^{\circ} \mathrm{C}$ kill bacteria and inactivate enzymes, although, as such temperatures are also likely to cause crop surface hardening, lower operating temperatures in the range $40 \mathrm{C}$ to $45^{\circ} \mathrm{C}$ as shown in Table 1 are generally more common place in solar dryers.

For many crops pretreatment is recommended such as washing, blanching and cutting into thin slices. Crops are generally harvested at moisture contents ranging from $16 \%$ to $30 \%$ wet basis and must be dried to a safe storage moisture contents given in Table 1. In grain drying, fissures that can arise from excessive moisture and temperature gradients lead to broken grains during milling reducing the milled cereal yield. Prompt packing in hermetically sealed containers is essential if for consumer acceptability higher safe storage moisture are used for example as is the case for some dried fruits. 
Table 1 Drying requirements for common crops (Farkas, 2004)

\begin{tabular}{|c|c|c|c|c|c|}
\hline \multirow[t]{2}{*}{ Material } & \multicolumn{2}{|c|}{$\begin{array}{l}\text { Molsture } \\
\text { content }\end{array}$} & \multirow{2}{*}{$\begin{array}{l}\text { Maximum } \\
\text { temperature } \\
\text { for drying } \\
\left({ }^{\circ} \mathrm{C}\right)\end{array}$} & \multirow{2}{*}{$\begin{array}{c}\text { Water to be } \\
\text { removed } \\
(\mathrm{kg} / \mathrm{t})\end{array}$} & \multirow{2}{*}{$\begin{array}{c}\text { Energy } \\
\text { required } \\
\left(\mathrm{kJ} / \mathrm{t} \times 10^{6}\right)\end{array}$} \\
\hline & Initial (\%) & Final $(\%)$ & & & \\
\hline Aoples & 80 & 24 & 70 & 736,8 & 1,502 \\
\hline Apricots & 85 & 18 & 65 & 817,1 & 1,666 \\
\hline Bananas & 80 & 15 & 70 & 823,5 & 1,679 \\
\hline Cabbage & 80 & 4 & 55 & 791,7 & 1,614 \\
\hline Carrots & 70 & 5 & 75 & 684,2 & 1,395 \\
\hline Cassava & 62 & 17 & & 542,2 & 1,105 \\
\hline Cauliflower & 80 & 6 & 65 & 787,2 & 1,605 \\
\hline Chillies & 80 & 5 & 65 & 789,5 & 1,610 \\
\hline Cocoa beans & 50 & 7 & & 462,4 & 0,943 \\
\hline Coffee beans & 55 & 12 & & 488,6 & 0,996 \\
\hline Coffee & 50 & 11 & & 438,8 & 0,895 \\
\hline Conifers & $30-40$ & $10-15$ & 50 & $222,2-294,1$ & $0,453-0,600$ \\
\hline Corn & 24 & 14 & 50 & 116,3 & 0,237 \\
\hline Figs & 80 & 24 & & 736,8 & 1,502 \\
\hline Fish, raw & 75 & 15 & 30 & 705,9 & 1,439 \\
\hline Fish, water & 75 & 15 & 50 & 705,9 & 1,439 \\
\hline Foliage trees & $25-35$ & $17-20$ & 50 & $96,4-187,5$ & $0,197-0,382$ \\
\hline Garlic & 80 & 4 & 55 & 791,7 & 1,674 \\
\hline Grapes & 80 & $15-20$ & 70 & $750,0-823,5$ & $1,529-1,679$ \\
\hline Green beans & 70 & 5 & 75 & 684,2 & 1,395 \\
\hline Green peas & 80 & 5 & 65 & 789,5 & 1,610 \\
\hline Groundnuts & 40 & 9 & 50 & 340,6 & 0,694 \\
\hline Guavas & 80 & 7 & 65 & 784,9 & 1,600 \\
\hline Maize & 35 & 15 & 60 & 235,3 & 0.480 \\
\hline Onions & 80 & 4 & 55 & 791,7 & 1,614 \\
\hline Peaches & 85 & 18 & 65 & 817,1 & 1,666 \\
\hline Pineapple & 80 & 10 & 65 & 777,8 & 1,586 \\
\hline Potatoes & 75 & 13 & 75 & 712,6 & 1,453 \\
\hline Prunes & 85 & 15 & 55 & 823,5 & 1,679 \\
\hline Rice & 24 & 11 & 50 & 146,1 & 0.298 \\
\hline Spinach & 80 & 10 & & 777,8 & 1,586 \\
\hline Sweet potato & 75 & 7 & 75 & 731,2 & 1,491 \\
\hline Wheat & 20 & 16 & 45 & 47,6 & 0,097 \\
\hline
\end{tabular}




\section{Drying processes}

Solar drying is a natural or an intentional solar energy induced mass transfer process resulting in the removal of water by evaporation successful drying requires (i) sufficient solar heat to withdraw moisture (ii) sufficiently dry air to absorb released moisture (iii) appropriate control of solar heat gain to avoid cooking the crop and (iv) adequate air circulation to remove the moisture. The rate of removal of moisture from a product is proportional to the difference between the average moisture content and the crop's equilibrium moisture content. The latter in equilibrium with air at a particular mean dry-bulb temperature and relative humidity at particular constant values of air relative humidity and temperature. The drying process takes place at a temperature that is between the temperatures of the air when entering the crop bed and when leaving the dryer. These processes can be summarised on a psychometric chart as shown in Figure 1. Air is heated at constant humidity ratio in

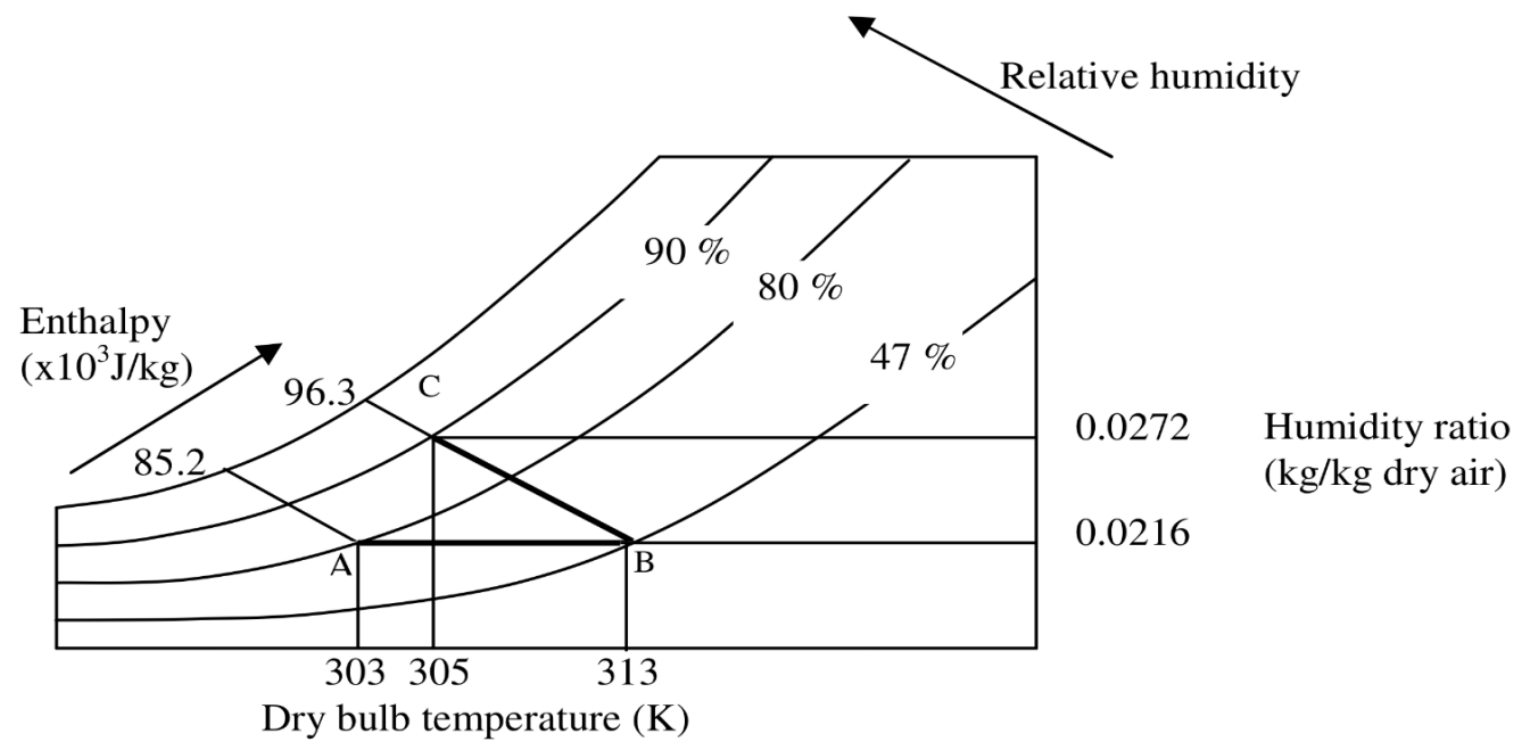

Figure 1. A psychometric chart showing an illustrative example of a drying process (Adapted from Munisa et al., 2013)

the solar collector from point $A$ to point $B$ to pass through the drying crop isoenthalpalically from point $B$ to point $\mathrm{C}$. The equilibrium temperature of drying air can be calculated by establishing a heat balance between molecules in moist air this becomes the saturated vapour pressure when air cannot take-up additional moisture. Pressure equalization causes moisture to migrate from a region of high to low vapour pressure.

Relative humidity is defined as the ratio of the mole fractions of water vapour in a present in the air to the maximum amount of vapour that the air can hold at a given temperature. Relative humidity is the ratio of the mass of water vapour to the mass of water vapour required to saturate air at that temperature. A dry-bulb temperature is the temperature at an ordinary thermometer. When a thermometer with a water-moistened wick-covered bulb is placed in a stream of unsaturated air, evaporation of water from the wick occurs that cools the bulb, the cooling is proportional to the evaporation rate, which is inversely proportional to the amount of water in the air. The final equilibrium steady-state temperature reached when the temperature of the thermometer remains unchanged is called the wet-bulb temperature. The psychometric wet-bulb temperature 
is close to but does not precisely correspond to the thermodynamic wet-bulb temperature reached by moist air and water when air is adiabatically saturated by evaporating water. The greater the differences between the amounts of water in the air and the saturation water capacity the greater the temperature depression between the dry-bulb and wet-bulb temperatures. The dew-point temperature is the temperature at which water vapour, being cooled at a constant mixture pressure and humidity ratio, begins to condense. Enthalpy is the relative heat content of moist air per unit mass of dry air above a chosen datum temperature. The enthalpy of moist air per unit mass is the sum of the enthalpies per unit mass of dry air and of superheated water vapour. chosen. The humidity ratio is the rate of the vapour pressure of a given moist air sample to that in a saturated air sample at the same temperature and pressure.

A crop drying rate is determined by the temperature and moisture content of the crop, the temperature, relative humidity and velocity of the drying air and thus, drying rate is of main importance. The drying time of each period depends on the nature of the product and the drying conditions. For hygroscopic agricultural products, typical drying rates exhibit up to four distinct periods as shown in Figure 2.

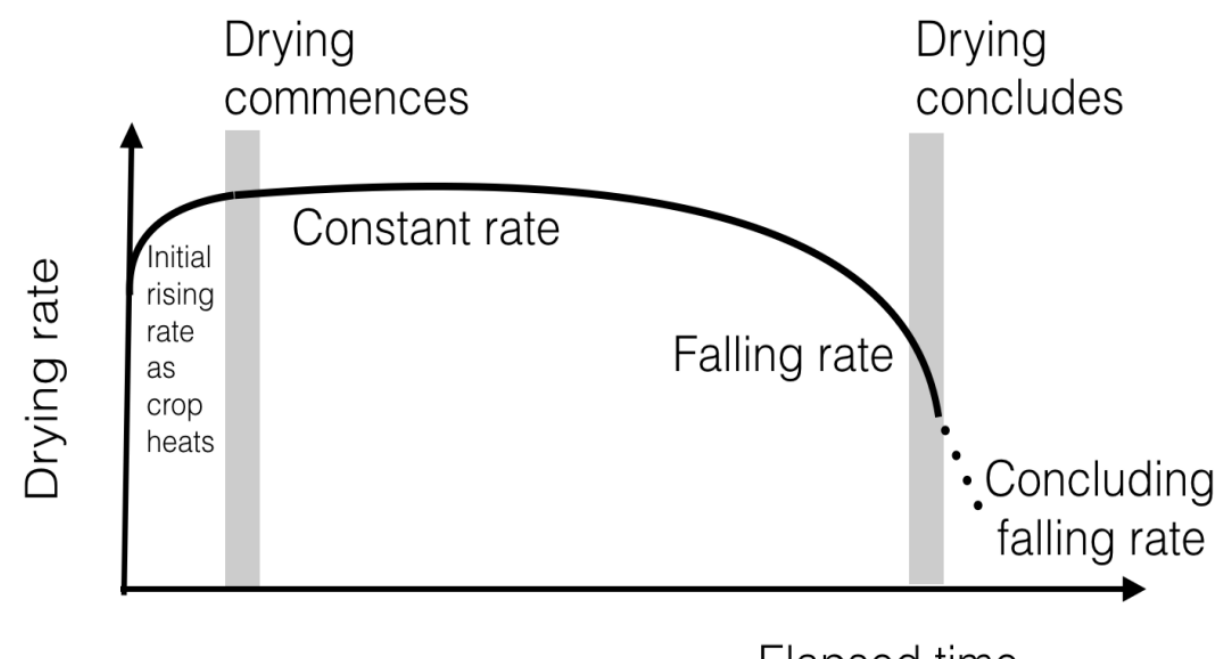

Figure 2. Drying Progression (Tomar et al., 2017)

These are

- Initially the crop heats until the drying temperature is achieved, at that juncture a constant drying rate ensues.

- constant-rate period during which the crop surface is saturated with water vapour and evaporation takes place continuously as at the material's surface is enough water to evaporate. A constant-rate period is not exhibited distinctly by many crop products as their initial moisture content allows the falling rate to be reached almost immediately as dry commences.

- falling rate period, when surface is not vapour saturated. Moisture diffusion is controlled by internal liquid movement while surface becomes continuously depleted. 
- a concluding falling rate period, where the moisture content continues to decrease until equilibrium is achieved. For many crops drying is completed before the onset of a concluding falling rare period is reached.

Figure 2 shows the four drying rates periods. This is followed by a falling drying rate caused by a continuous reduction in the rate of transfer of moisture from the crop's interior. decreases until the crop surface is no longer saturated. Water activity limit is defined by a relationship between the prevailing partial pressure of water, the partial pressure of pure water, at the same temperature and the relative humidity of the crop at the same temperature. Below the water activity limit, microorganisms stop growing. Beuchat (1981).

Exergetic analyses of dryers have been undertaken (Onyegegbu et al., 1994; Celma and Cuadros, 2009). The inclusion of a solar chimney to maintain the air enclosed in the chimney at a higher temperature than ambient enhances buoyant air flow in natural circulation dryers (Bassey et al., 1994; Ferreira et al., 2008; Afriyie et al., 2009; Das et al., 1989) and PV powered fans have also been used (Mumba 1996; Barnwal and Tiwari, 2008; Punlek et al., 2009). Roof-integrated air-heating solar collectors have been used for solar dryers (Roman et al, 2009) in temperate climates, their output of heated air can also be used to heat farm buildings when not required for drying (Henricksson and Gustafsson, 1986).

Dryers that include a biomass back-up heater (Bena and Fuller, 2002), energy storage (Ayensu and Asiedu Bondzie, 1986) or both (Madhlopa and Ngwalo, 2007) can continue the drying process from the day into the evening and night (Akyurt and Selcuk, 1973). Energy storage has been accomplished by including sensible heat storage, for example, in rock-beds (Chauhan et al., 1996, Jain, 2005; 2007) and by the use of phase change materials (Enibe, 2002). Heat pumps have been employed to increase drying air temperature (Best et al, 1994, Fadhel et al, 2011) and desiccants have been used to aid moisture removal (Thoruwa et al., 1996; Mahmouda and Ball,1991; Hodali and Bougard, 2001)

The very extensive previous literature available on different types of solar dryers, their performance in particular climates and with specific crops has been bright together in several reviews (Sodha and Chandra, 1094; Ekechukwu, 1999, Ekechukwu and Norton, 1999a, 1999b; Murthy, 2009; Sharma et al., 2009; Fudholi et al., 2010; Venkataraman et al., 2012). Solar drying has been employed to dry grain (Radajewski et al., 1987; Mohmouda and Ball, 1991; Tiwari et al., 1994; Fraser and Muir, 1980; Tayeb, 1986; Roa and Macedo 1976) and rice (Basunia and Abe, 2001; Zaman and Bala, 1989; Bala and Wood, 1994; Janjai et al., 1994). A very broad range of dried fruits have been produced using a variety of solar dryers. Some examples of solar dried fruits include bananas (Schirmer et al., 1996; Amer et al., 2010; Smitabhindu et al., 2008; Koua et al., 2009; Janjai et al., 2009), papaya (Narinesingh, and Mohammed-Maraj, 1998), mangos (Koua et al., 2009), apricots (Sarsilmaz et al., 2000; Togrul and Pehlivan 2002), figs (Doymaz, 2005), pumpkins (Sacilik, 2007)), apples (Aktas et al., 2009), pineapples (Bala et al., 2003), plums (Tarhan 2007), strawberries (El-Beltagy et al., 2007), grapes (Yaldiz, 2001; Jairaj et al., 2009; Pangavhane and Sawhney, 2002; Fadhel et al., 2005; Barnwal and Tiwari, 2008) and mulberries (Akbulut and Durmus, 2010; lemons, usually sliced, (Chen et al., 2005) and the peel of prickly pears (Lahsasni et al., 2004). In multiple locations, many herbs and spices are, as a matter of course, dried in the sun or in solar dryers (Muller et al., 1989; Janjai and Tung, 2005; Prasad et al., 2006; Janjai et al., 2008; Kumar and Tiwari 2006; Arslan and Ozcan, 2008) as are chillis (Hossain et al., 2005; Hossain and Bala, 2007; Banout, 2011) and green (Akpinar and Bicer, 2008) and red (Kooli et al., 2007) 
peppers. Among the dried vegetables produced using solar dryers are cauliflowers (Kadam and Samuel 2006), coriander (Chauhan et al., 1996), onion flakes (Kumar and Tiwari, 2007) and tomatoes (Sacilik et al., 2006). Solar drying has been used to dry root crops, usually cut into slices, including cassava (Ekechukwu and Norton, 1997;1998; Olufayo and Ogunkunle,1996; Koua et al., 2009) and sweet potatoes (Diamante and Munro, 1993; Hatamipour et al., 2007, Bechof et al., 2009). Dried seeds have been produced using solar dryers (Patil and Ward, 1989; Williamson et al., 2008). Solar dryers have also been used successfully for specialist high-value products such as coffee beans (Philips, 1965) and pistachio nuts (Midilli and, Kucuk, 2003). In addition to drying crops, solar drying has also been adopted for drying products as diverse as timber (Headley. 1998, 2000; Lina et al., 2009, Taylor and Weir, 1985), fermented dairy products (Bahnasawy and Shenana, 2004) and fish (Fudholi, 2010).

Typical drying times in solar dryers range from one to three days depending on the dryer type, the intensity and duration of solar radiation incident, air flow rates, drying chamber humidity, ambient humidity and the temperature-dependent mass transfer coefficients that determine the drying kinetics of the crop to be dried (Tripathy and Kumar, 2009). An air flow will continue to take-up moisture that is available at the moist surface of a crop until the air flow is fully saturated. The later is determined by a temperature dependent absolute maximum humidity. At higher temperatures, the absolute humidity is higher. So, when an air flow is heated by solar energy, the moisture content remains the unchanged but the relative humidity is lower so the that airflow is now able to take-up more moisture from a crop once it flows in the drying chamber.

The optimal drying time is a trade-off between achieving;

- sufficiently fast crop-throughout to make best economic use of the dryer and to, where possible, compete drying, preferably in one day, to obviate the need for nocturnal crop storage

- high-quality product without excessive heating degrading the crop to give a lower market price.

Drying time can be hastened by;

- heating the crop by directly solar heating and/or indirectly, via a solar heated air flow, so that the moisture can be vapourised more readily.

- crop pre-preparation including slicing to allow a larger crop surface area to be available to release moisture, break into long moisture migration paths and/or dense hydrophobic crop skins layers. As can be seen in Figure 3 , the effect of slicing can reduce drying times significantly. 


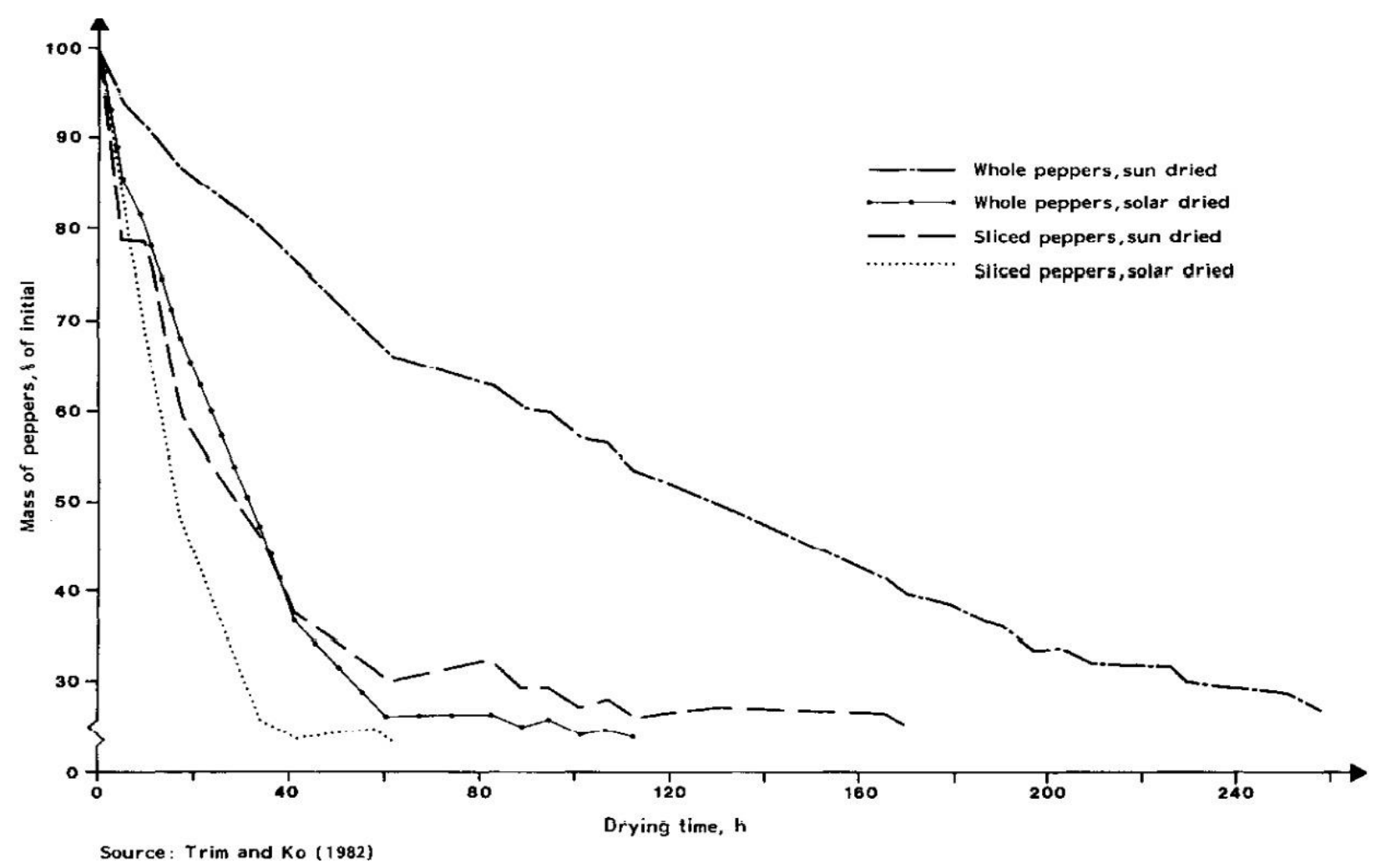

Figure 3. Effect of pre-preparation on drying times for solar drying and open-sea dryers of red peppers (Trim and Ko, 1982).

\subsection{Types of solar thermal dryer}

The types of solar thermal dryers commonly available are illustrated in Figures 4 and 5 .

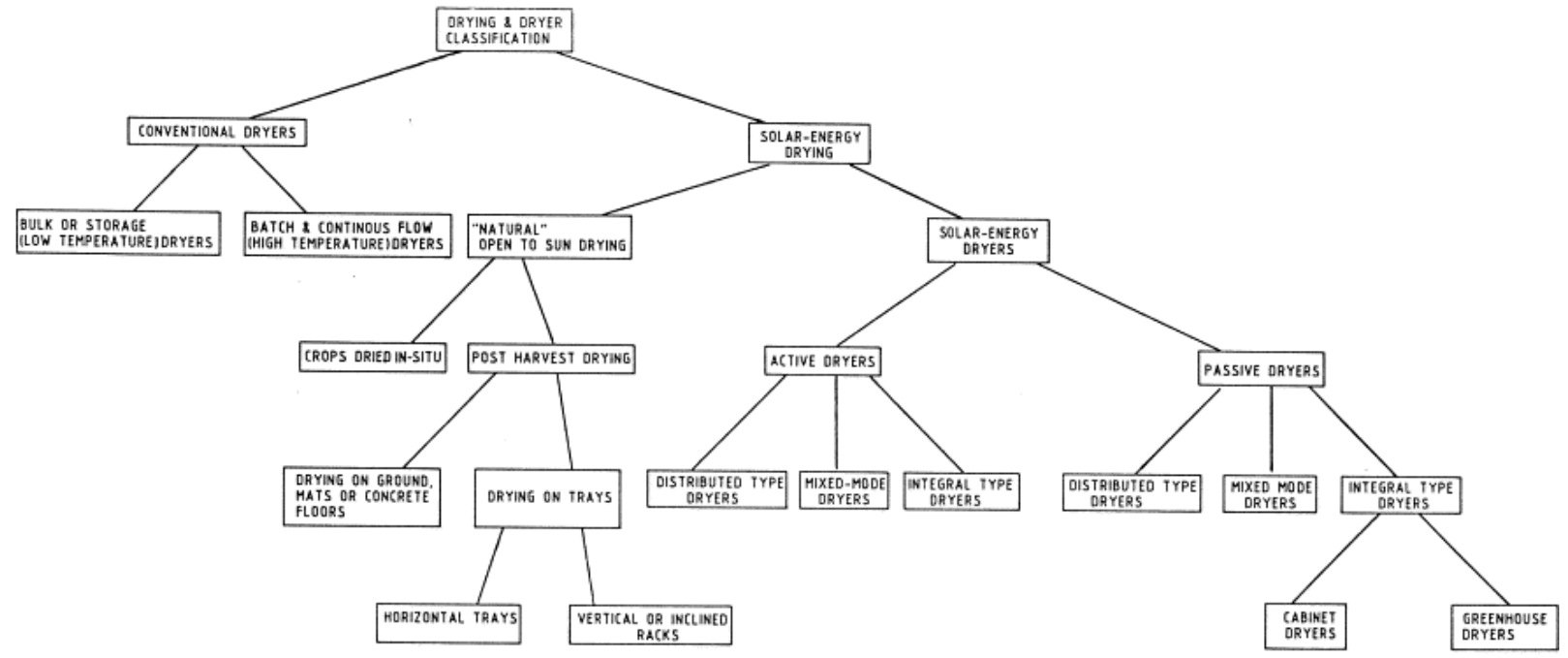

Figure 4. Taxonomy of solar drying (Ekechukwu and Norton, 1999b) 


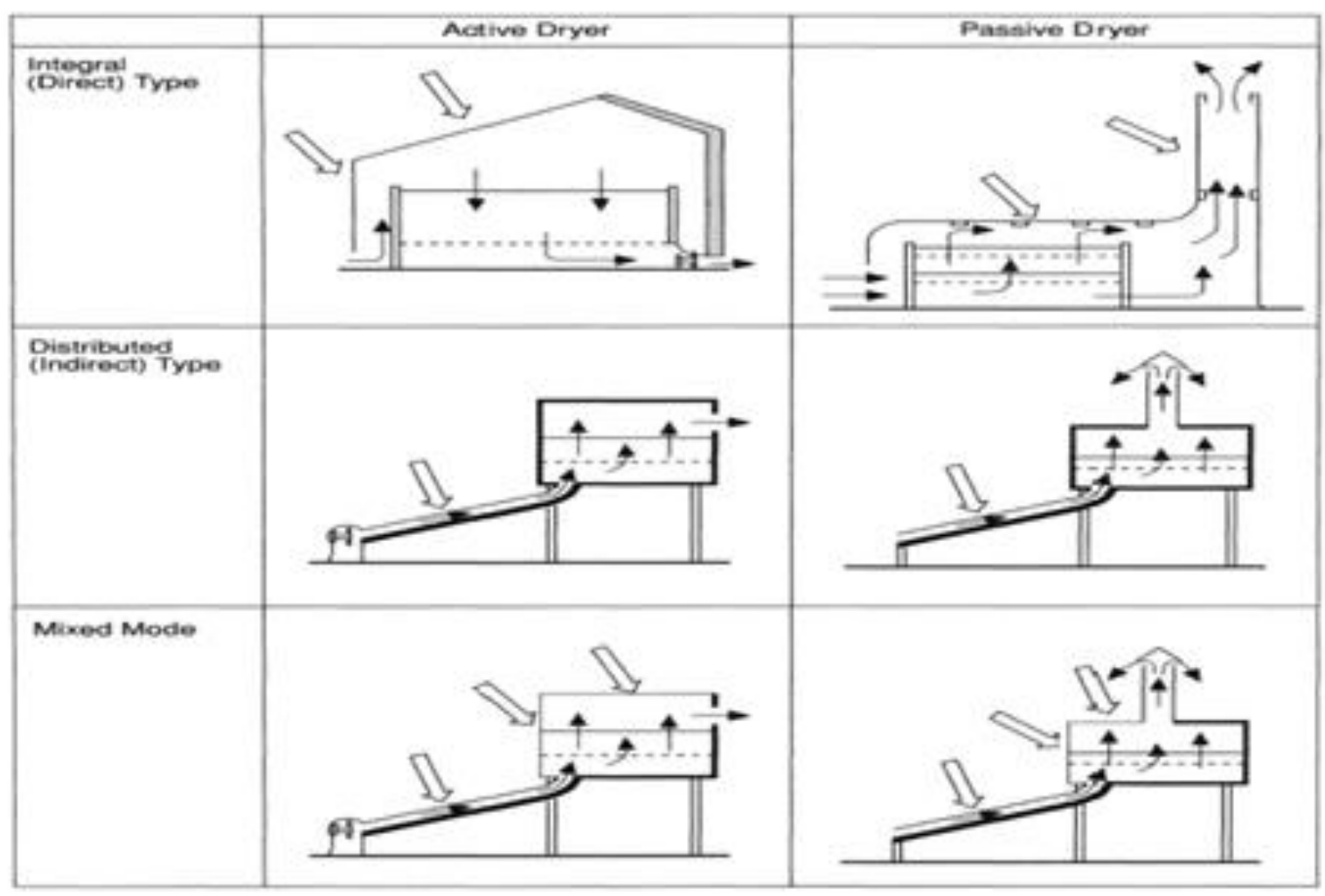

Figure 5. Solar dryer's classification (Ekechukwu and Norton et al, 1999a)

Dryers in which crops are directly exposed to solar radiation are termed direct solar dryers. A crop is directly heated by sun in most cabinet solar dryers (Singh et al., 2006; Datta et al., 1988; Sharma et al., 1990) though indirectly heated cabinet dryers have been realised (Sreekumar et al., 2008; Goyal and Tiwari, 1999).

In an indirect solar dryer, the crop is exposed to warm air from an air-heating solar collector and not directly to the sun. Indirect and direct solar dryers are, broadly speaking applicable to different, but overlapping ambient conditions as shown indicatively in Figure 8. It is important to note that for a given location conditions are changeable (El-Sebaii et al., 2002; Sharma et al., 1992; Singh et al., 2004). 


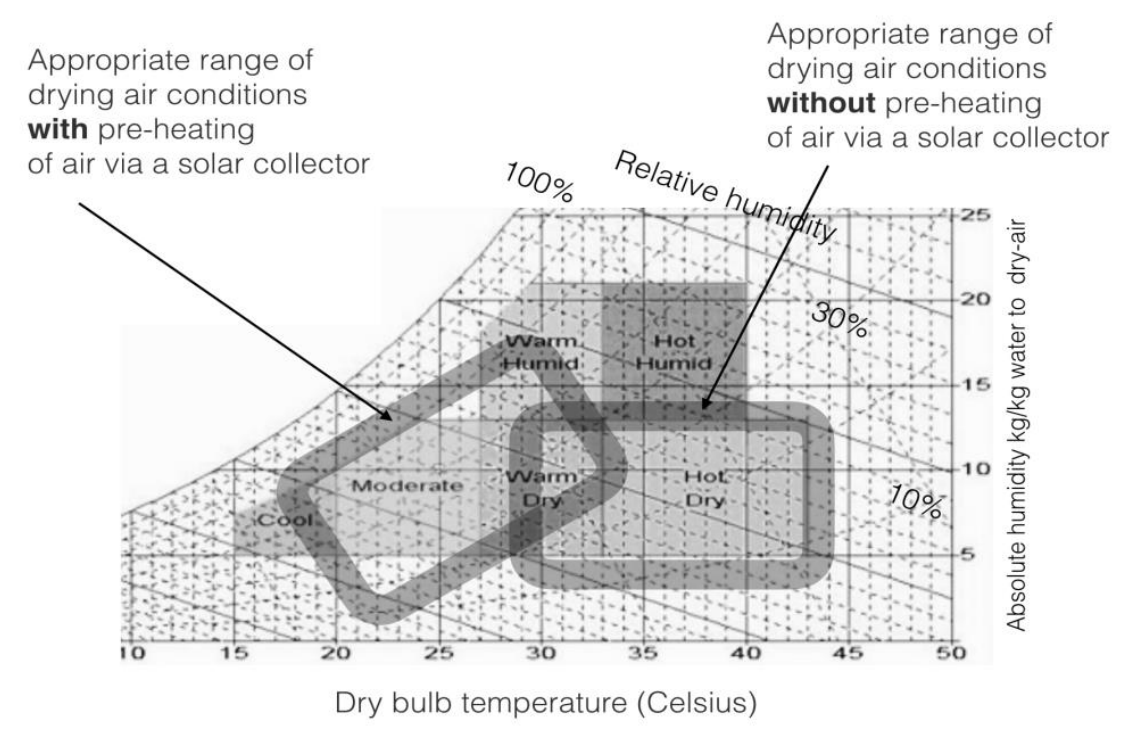

Figure 6. Indicative ambient conditions for direct and indirect solar dryers

In a mixed mode dryer (Forson et al., 2007a; 2007b), a crop is simultaneously exposed directly to incident solar heat gain and a flow of solar-heated air. As fruit and vegetable crops are dried in an air flow browning ensues due to a combination of enzymatic and non-enzymatic browning reactions (Krokida et al., 1998). For different dryers, operational conditions and initial crop parameters drying method significant differences have been observed in the browning reactions that crop undergoes during drying.

A direct solar dryer consists of an enclosure with a transparent cover and/or side panels. To enhance solar energy collection efficiency, the internal surfaces of the enclosure are often dark in colour. Heat generated from the absorption of the solar radiation within the crops as well as at the surfaces of the enclosure cause the removal of moisture. Direct dryers are simple to construct. Compared to open-sun drying, direct solar dryers are more hygienic and can heat the crops to higher temperatures. As they are normally built in quite small sizes, direct dryers are only intended to dry small quantities of, often high value, crops. However, without knowledgeable and experienced operation, slow drying rates, overheating and changes in crop colour and flavour can ensue due to the direct exposure to sun. In direct dryers, it can be difficult to control effectively the rate of moisture removal. At the start of the drying process, it is often necessary to close the outlet air holes to allow the temperature of air in the dryer to rise. Water evaporates from the crop and condenses on the inside of the transparent cover and thus reducing the amount of solar radiation transmitted to the dryer interior. This condition is subsequently improved by opening the outlet vents, but in turn it causes temperature inside the dryer to fall. A chimney as shown in Figure 7 is usually incorporated in natural convection direct dryers to increase the air-flow through the crop bed. 


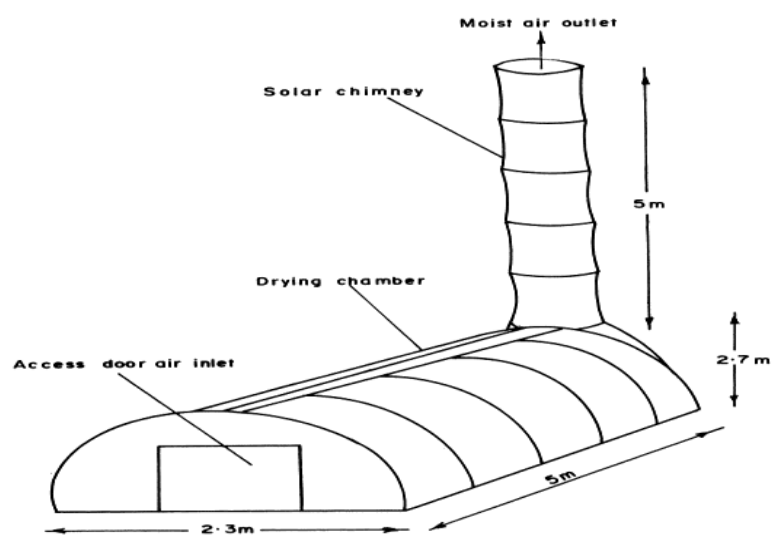

Figure 7. A greenhouse solar dryer incorporating a chimney (Ekechukwu and Norton, 1995).

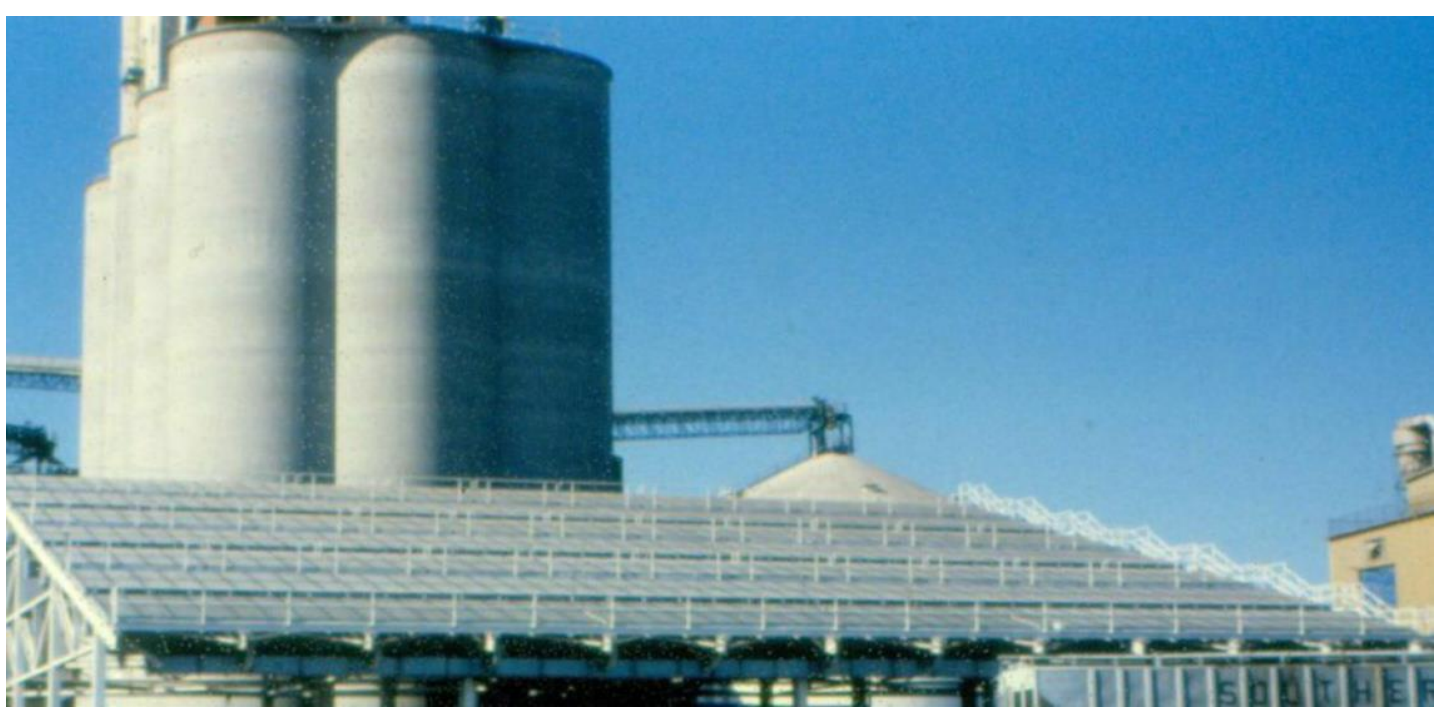

Figure 8. A large-scale forced convection solar dryer

Indirect solar dryers are those in which the crops are placed in an enclosed drying cabinet there by being shielded from direct exposure to solar radiation. An indirect solar dryer basically consists of three major components: an air heater, which is used to raise the temperature of the drying air, a drying chamber which is the enclosure that accommodates the crops and a fan to convey air between them. Large-scale forced indirect convection solar dryers, such as that shown in Figure 8, generate the high air-flow rates required to overcome pressure drops through deep drying crop beds which makes them suitable for drying very large crop volumes. Higher solar energy collection efficiency also results generally from the consistently controlled higher air velocities in the solar collector.

An alternative to the installation of specialist air-heating solar collectors as shown in Figure 6 is the lower cost fabrication of roof-integrated collectors as shown in Figure 9 or the use of roof-mounted transpired air-heating collectors as shown in Figure 10. 

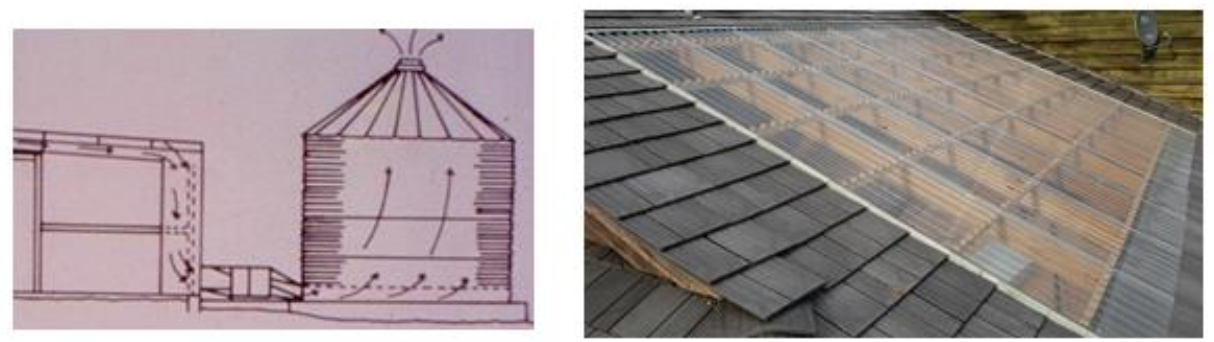

Figure 9. A roof-mounted air-heating solar collector and the integration of air-flow to a drying silo

Figure 10. A walnut dryer constructed in California using transpired air-heating solar collector (Hollick, 1999).

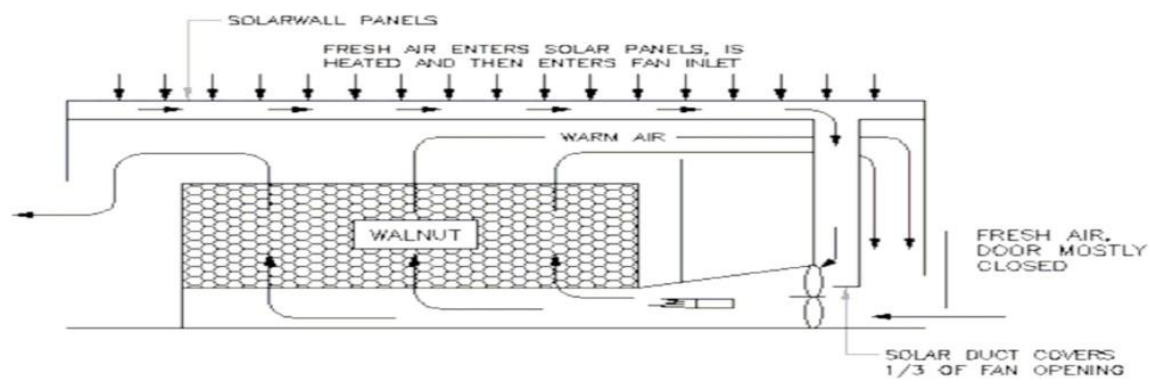

Drying is a continuous process where the moisture content, air and crop temperature and the humidity of the air all change simultaneously. The introduction of a fan enables more direct control of the flow rate to archive optimal drying, particularly in the transition from initial falling to constant drying rates, than can usually be achieved by the operation of flaps and louvres in natural circulation dryers. Forced convection dryers require a electrical or fossil fuel source of power to operate the fan. This is the most significant obstacle to their deployment in remote rural areas where such power has been either rarely available, unreliable and/or expensive. With the continuing reductions in the cost of photovoltaics, the use of a photovoltaic array to power a fan has become practicable. Where drying takes place over several days, the dryer needs to be designed to avoid nocturnal reabsorption of moisture. This can be accomplished by closing-off all air ducts with dampers. An alternative is to continue drying using stored energy or other fuel sources.

Air heated in the collector passes through the drying chamber where the crop to be dried is placed on one or more porous trays. The air passes through the wet crop bed and becomes nearly saturated, thus lowering its temperature to nearly that of the ambient air, before it exits via a chimney. This type of dryer is used when the crop being dried can be damaged if it is exposed to the direct solar radiation. Many crops can be dried in deeper layers, therefore requiring a smaller installation area. However, natural convection indirect solar dryers are prone to poor performance. Since the air above the crop bed is not substantially different in temperature from that of the ambient air, which is also damp in humid regions, the resulting buoyancy forces, which are proportional to the temperature difference, are very small, and in turn often low air-flow rates. A combination of direct and indirect solar dryers is termed mixed mode dryers. They normally comprise indirect dryers with transparent drying chamber tops and/ or sides. 
Mixed mode dryers are also suitable to drying crops to which the exposure to sunlight is considered essential for the required colour or flavour development in the dried product such as Arabia coffee beans. A solar dryer with transparent or translucent walls is designed to transmit the greatest amount of incident solar energy into the dryer. Surfaces inside the dryer are dark in colour to absorb that transmitted energy to heat internal surfaces. Energy is then transferred from the heated surfaces to the air in the dryer, primarily by convection. Circulated by natural or forced convection, air then transfers energy to the crop where it removes water from the crop to the air.

Typical drying durations to safe storage moisture content can range from one to three days, again depending on solar radiation intensity and duration, air movement, the prevalence of lower ambient humidities, and the quantity and type of food. As can be seen from Figure 11 forced circulations leads to less thermal stratification in the dryer and generally archives uniform drying without additional operational interventions. To achieve similarly uniform drying in natural circulation dryers, crop trays need to usually rotated daily whilst drier crops in upper parts of the drying chamber are often moved to continue drying on lower racks. The crop is allowed to cool completely before it is stored in airtight containers.

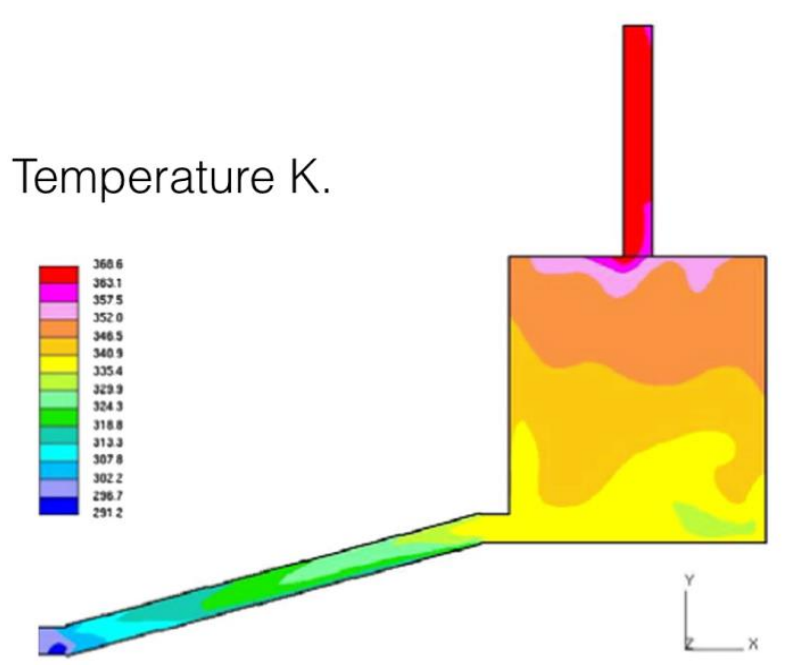

Natural circulation.

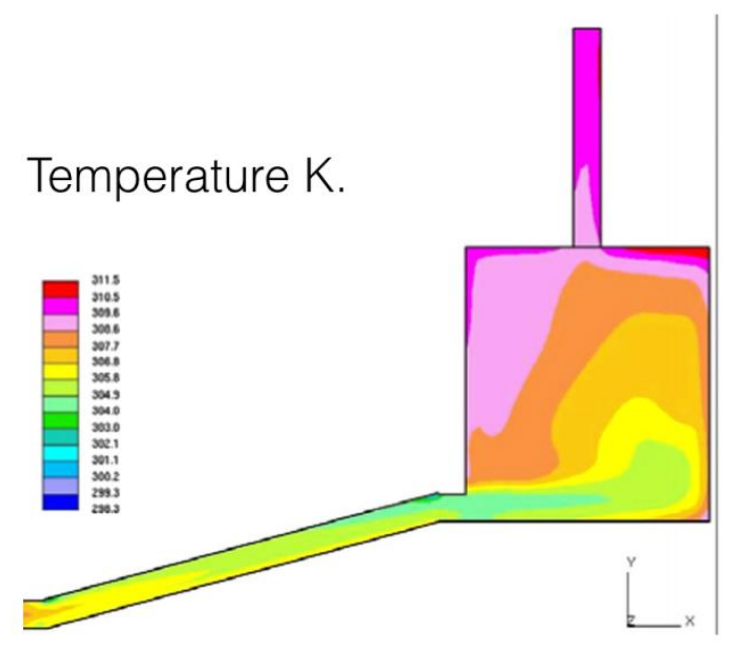

Forced circulation.

Figure 11. Predicted temperatures in cabinet solar dryers with natural and forced circulation (Ghaffari and Mehdipour, 2015) 


\subsection{Solar dryers with fans powered by photovoltaic modules}

The capital cost of photovoltaic installations has reduced globally. In certain jurisdictions, their various market interventions have been made to encourage the use of photovoltaics as a contribution to the decarbonisation of electricity production. A photovoltaic array can be used to power the fan in a forced circulation solar dryer as shown in Figure 12 enabling (i) autonomy in use that avoids external recurrent energy costs and (ii) the extension of the use of forced circulation dryers to remote or portable uses.

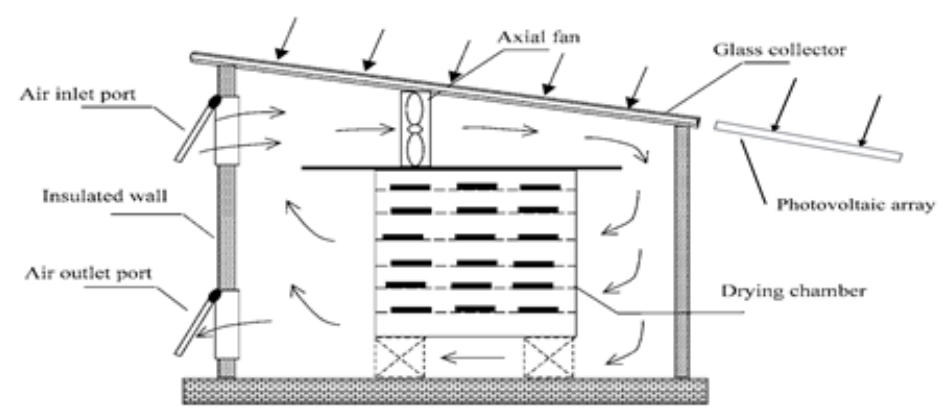

Figure 12. A forced circulation dryer with a photovoltaic powered fan

Electricity provided by a photovoltaic array can be used to power vacuum dryers where heat is supplied by contact conduction, radiation or microwaves and the vapour produced removed by a vacuum system. Similarly, electricity from a photovoltaic array can be used to provide the refrigeration required for the drying technique where the solvent is frozen prior to drying to be subsequently sublimed (that is, passed to the gas phase directly from the solid phase) below the melting point of the solvent. Such freeze drying is often carried out under high vacuum to allow drying to proceed swiftly. As this process maintains complex internal solide structures, low density, highly porous products are produced able to regain moisture rapidly. Freeze drying is one of the best methods of retaining the initial properties of biological materials such as foods. Freeze drying is becoming used increasingly to preserve foods for which it is important to keep intact protein quality, vitamins and other bioactive compounds.

\section{Conclusion}

Solar dryers can include a wide range of modes of air-flow, arrangement via which solar energy is harvested to accommodate the distinctive process optimisations required for the production of high quality different corps. There are, however, a generic set of attributes that are distinctive of specific generic solar dryer types as illustrated in Figure 13. 


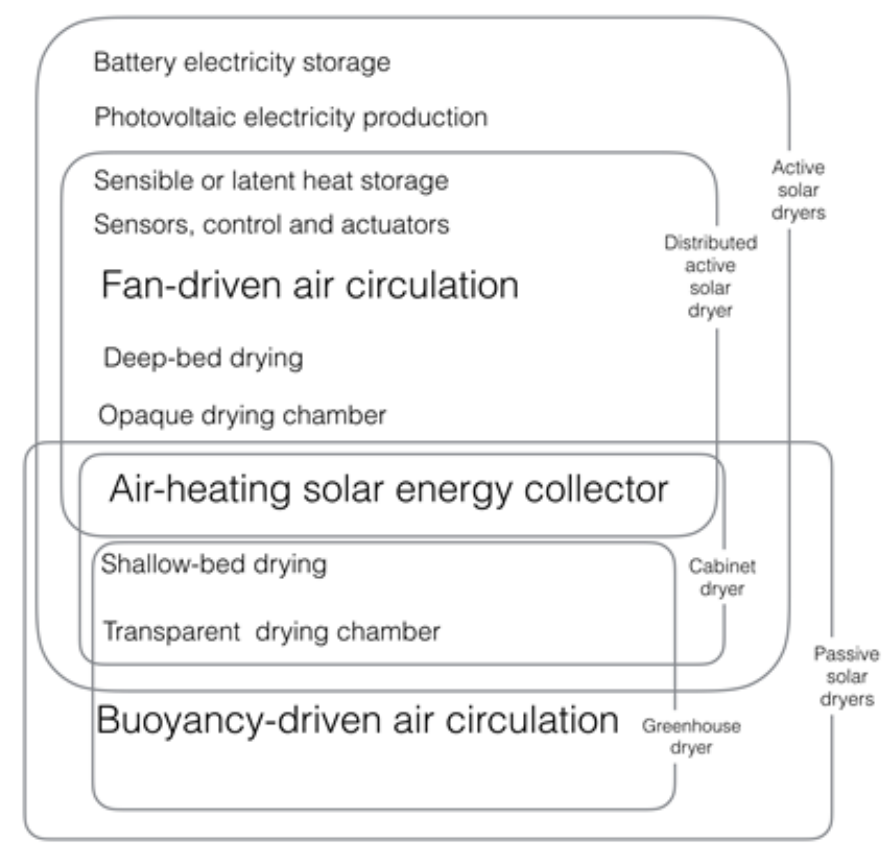

Figure 13. Groupings of dryer attributes with generic dryer type

Unlike water heating and electricity generation, drying crops is a direct and longstanding use of solar energy. Nevertheless, as shown in Figure 14, careful consideration of the crop characteristics and ambient conditions must inform dryer design to achieve economic viability. Extensive examples of the use of solar drying now exist each with a distinct characteristic depending of the crop and climate. New developments are informed increasingly by the experience of operational practice.

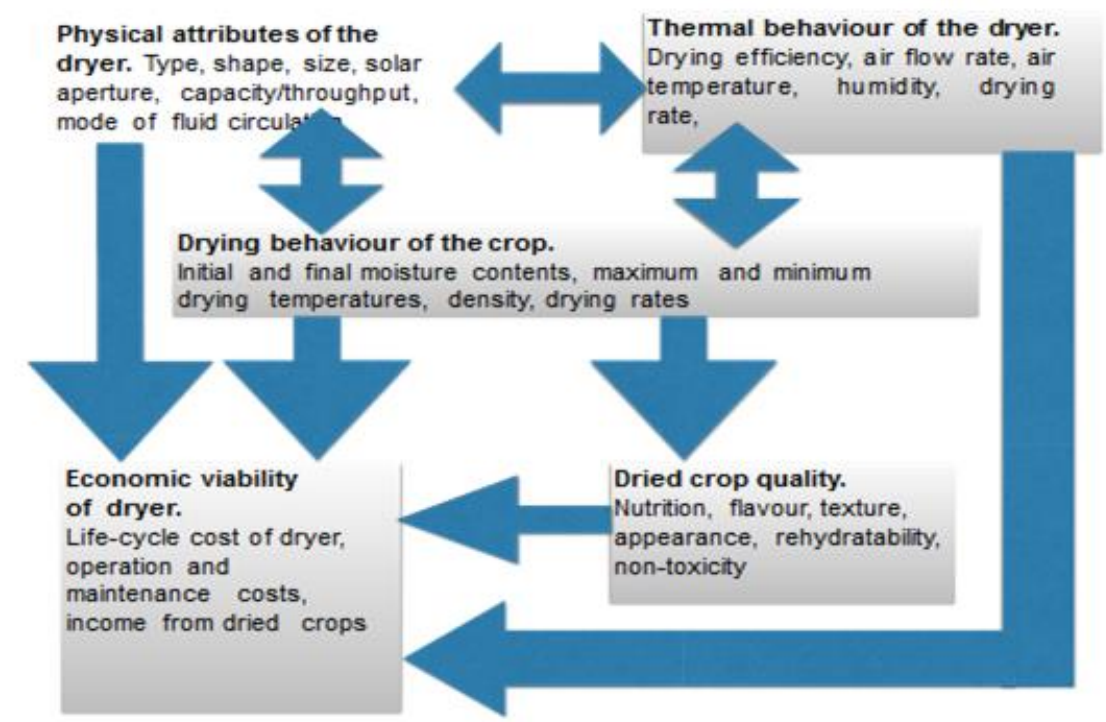

Figure 14. Factors determining the economic viability of a solar dryer (Tomar et al, 2017) 


\section{References}

Afriyie JK, Nazha MAA, Rajakaruna $\mathrm{H}$ and Forson FK. Experimental investigations of a chimney-dependent solar crop dryer. Renewable Energy, 2009; 34: 217-222.

Akbulut A and Durmus A. (2010) Energy and exergy analyses of thin layer drying of mulberry in a forced solar dryer. Energy, 35,1754-1763.

Akpinar EK and Bicer Y. (2008) Mathematical modelling of thin layer drying process of long green pepper in solar dryer and under open sun. Energy Conversion and Management, 49: 1367-1375.

Aktas M, Ceylan I and Yilmaz S. (2009) Determination of drying characteristics of apples in a heat pump and solar dryer. Desalination, 239: 266-75.

Akyurt M and Selcuk MK. (1973) A solar drier supplemented with auxiliary heating systems for continuous operation. Solar Energy, 14: 313-3320

Amer BMA, Hossain MA and Gottschalk K. (2010) Design and performance evaluation of a new hybrid solar dryer for banana. Energy Conversion Management, 51, 813-820

Arslan D and Ozcan MM. (2008) Evaluation of drying methods with respect to drying kinetics, mineral content and colour characteristics of rosemary leaves. Energy Conversion and Management, 49: 1258-1264.

Ayensu A, and Asiedu Bondzie V. (1986) Solar drying with convective self-flow and energy storage. Solar and Wind Technology, 3: 273-279.

Bahnasawy AH and Shenana ME. (2004) A mathematical model of direct sun and solar drying of some fermented dairy products (Kishk). J Food Engineering, 61: 309-319.

Bala BK and Wood JL. (1994) Simulation of the indirect natural convection solar drying of rough rice. Solar Energy, 53: 259-266.

Bala BK, Mondol MRA, Biswas BK, Das Chowdury BL and Janjai S. (2003) Solar drying of pineapple using solar tunnel drier. Renewable Energy, 28: 183-190.

Banout J, Ehl P, Havlik J, Lojka B, Polesny Z and Verner V. (2011) Design and performance evaluation of a double-pass solar drier for drying of red chilli (Capsicum annum L.). Solar Energy, 85: 506-515.

Barnwal P and Tiwari GN. (2008) Grape drying by using hybrid photovoltaic-thermal (PV/T) greenhouse dryer: an experimental study. Solar Energy, 82, 1131-1144. 
Bassey MW, Oosthuizen PH and Sarr J. (1994) Using heated chimneys and reduced collector air gap height to improve the performance of indirect passive solar dryers. Renewable Energy, 4: 169-178.

Basunia MA and Abe T. (2001) Thin-layer solar drying characteristics of rough rice under natural convection. J Food Engineering. 47: 295-301.

Bechoff A, Dufour D, Dhuique-Mayer C, Marouze C, Reynes M and Westby A. (2009) Effect of hot air, solar and sun drying treatments on provitamin A retention in orange-fleshed sweet potato. Journal of Food Engineering, 92: 164-171.

Bena B and Fuller RJ. (2002) Natural convection solar dryer with biomass back-up heater. Solar Energy, 72 : 75-83.

Belessiotis V. and Delyannis, E. (2011) Solar Drying, Solar Energy, 85(8) 1665-1691

Best R, Soto W, Pilatowsky I and Gutierrez LJ. (1994) Evaluation of a rice drying system using a solar assisted heat pump. Renewable Energy, 5: 465-468.

Chauhan PM, Choudhury C and Garg HP. (1996) Comparative performance of coriander dryer coupled to solar air heater and solar air-heater-cum-rock bed storage. Applied Thermal Engineering, 16: 475-486.

Chavan BR, Yakupitiyage A, Kumar S. (2008) Mathematical modelling of drying characteristics of Indian mackerel (rastrilliger kangurta) in solar-biomass hybrid cabinet dryer. Drying Technology Int J, 26:1552-62,

Chen $\mathrm{H}-\mathrm{H}$, Hernandez CE and Huang T-C. (2005) A study of the drying effect on lemon slices using a closedtype solar dryer. Solar Energy, 78: 97-103.

Das SK and Kumar Y. (1989) Design and performance of a solar dryer with vertical collector chimney suitable for rural application. Energy Conversion and Management, 29:1 29-135.

Datta G, Garg HP, Ray RA and Prakash J. (1988) Performance prediction of a cabinet-type solar drier. Solar and Wind Technology, 5: 289-92.

Diamante LM and Munro PA. (1993) Mathematical modelling of the thin layer solar drying of sweet potato slices. Solar Energy, 51, 271-276.

Doymaz I. (2005) Sun drying of figs: an experimental study. J Food Engineering, 71: 403-407.

Ekechukwu OV. (1999) Review of solar energy drying I: an overview of drying principles and theory. Energy Conversion and Management, 40; 593-613. 
Ekechukwu OV and Norton, B (1995) Design and Measured Performance of a Solar Chimney for Natural Circulation Solar Dryers, ASME Journal of Solar Energy Engineering, 118, 69-71.

Ekechukwu OV and Norton B. (1999a) Review of solar energy drying II: an overview of drying technology. Energy Conversion and Management, 40: 615-655.

Ekechukwu OV and Norton B. (1999b) Review of solar energy drying III: low temperature air-heating solar collectors for crop drying applications. Energy Conversion and Management, 40: 657-67.

El-Beltagy A, Gamea GR and Amer Essa AH. (2007) Solar drying characteristics of strawberry. J Food Engineering, 78: 456-464

El-Sebaii AA, Aboul-Enein S, Ramadan MRI and El-Gohary HG. (2002) Experimental investigation of an indirect type natural convection solar dryer. Energy Conversion and Management, 43: 2251-2266.

Enibe SO. (2002) Performance of a natural circulation solar air heating system with phase change material energy storage. Renewable Energy, 27: 69-86.

Fadhel A, Kooli S, Farhat A and Bellghith A. (2005) Study of the solar drying of grapes by three different processes. Desalination, 185: 535-541.

Ferreira AG, Cristina VM, Marcio FBC, and Ramon MV. (2008) Technical feasibility assessment of a solar chimney for food drying. Solar Energy, 82: 198-205.

Forson FK, Nazha MAA, Akuffo FO and Rajakaruna H. (2007a) Design of mixed-mode natural convection solar crop dryers: Application of principles and rules of thumb. Renewable Energy, 32: 2306-2319.

Forson FK, Nazha MAA and Rajakaruna H. (2007b) Modelling and experimental studies on a mixed-mode natural convection solar crop-dryer. Solar Energy, 81: 346-357

Fudholi A, Sopian K, Ruslan MH, Alghoul MA and Sulaiman MY. (2010) Review of solar dryers for agricultural and marine products. Renewable and Sustainable Energy Reviews, 14: 1-30.

Fraser BM and Muir WE. (1980) Energy consumptions predicted for drying grain with ambient and solar heated air in Canada. J Agricultural Engineering Research, 25: 325-31.

Ghaffari, A and Mehdipour R (2015) Modelling and Improving the Performance of a Cabinet Dryer using Computational Fluid Dynamics, International Journal of Food Engineering, 11, 157-172.

Goyal RK and Tiwari GN. (1999) Performance of a reverse flat plate absorber cabinet dryer: a new concept. Energy Conversion and Management, 40: 385-92. 
Hatamipour MS, Kazemi HH, Nooralivand A and Nozarpoor A. (2007) Drying characteristics of six varieties of sweet potatoes in different dryers. Food Bioproduction Process, 85:171-177.

Headley OSC. (1998) Solar thermal applications in the West Indies. Renewable Energy, 15: 257-263.

Headley OSC. (2000) Solar crop drying in the West Indies. World Renewable Energy Congress VI. 934-939.

Henricksson R and Gustafsson G. (1986) Use of solar collectors for drying agricultural crops and for heating farm buildings. Energy in Agriculture, 5:139-150

Hodali R and Bougard J. (2001) Integration of a desiccant unit in crops solar drying installation: optimisation by numerical simulation. Energy Conversion and Management, 42, 1543-1558.

Hossain MA, Woods JL and Bala BK. (2005) Optimisation of solar tunnel drier for drying of chilli without colour loss. Renewable Energy, 30; 729-742.

Hossain MA and Bala BK. (2007) Drying of hot chilli using solar tunnel dryer. Solar Energy, 81; 85-92.

Jain D. (2007) Modelling the performance of the reversed absorber with packed bed thermal storage natural convection solar crop dryer. J Food Engineering, 78: 637-647.

Jain D. (2005) Modelling the performance of greenhouse with packed bed thermal storage on crop drying application. J Food Engineering, 71:170-178.

Jain D and Tiwari GN. (2003) Thermal aspects of open sun drying of various crops. Energy, 28: 37-54

Jairaj KS, Singh SP and Srikant K. (2009) A review of solar dryers developed for grape drying. Solar Energy, 83:1698-1712.

Janjai S, Lamlert N, Intawee P, Mahayothee B, Bala BK, Nagle M, et al. (2009) Experimental and simulated performance of a PV-ventilated solar greenhouse dryer for drying of peeled longan and banana. Solar Energy, 83: 1550-1565.

Janjai S, and Tung P. (2005) Performance of a solar dryer using hot air from roof-integrated solar collectors for drying herbs and spices. Renewable Energy, 30: 2085-2095.

Janjai S, Srisittipokakun N, and Bala BK. (2008) Experimental and modelling performances of a roof-integrated solar drying system for drying herbs and spices. Energy, 33: 91-103.

Janjai S, Esper A, and Muhlbauer W. (1994) A procedure for determining the optimum collector area for a solar paddy drying system. Renewable Energy, 4:409-416 
Kadam DM and Samuel DVK. (2006) Convective flat-plate solar heat collector for cauliflower drying. Biosystems Engineering, 93:189-98.

Kooli S, Fadhel A, Farhat A and Belghith A. (2007) Drying of red pepper in open sun and greenhouse conditions: Mathematical modelling and experimental validation. Journal of Food Engineering 79: 1094-1103.

Koua KB, Fassinou WF, Gbaha P and Toure S. (2009) Mathematical modelling of the thin layer solar drying of banana, mango and cassava. Energy, 34;1594-1602.

Krokida M.K., Tsami E. and Maroulis ZB. (1998) Kinetics on colour changes during drying of fruits and vegetables, Drying Technology, 16, 667-685.

Kumar A and Tiwari GN. (2007) Effect of mass on convective mass transfer coefficient during open sun and greenhouse drying of onion flakes. Journal of Food Engineering, 79: 1337-1350.

Kumar A and Kandpal TC. (2005) Solar drying and $\mathrm{CO}_{2}$ emission mitigation: potential for selected cash crops in India. Solar Energy, 78: 321-329.

Kumar A and Tiwari GN. (2006) Thermal modelling of a natural convection greenhouse drying system for jaggery: an experimental validation. Solar Energy, 80: 1135-1144.

Lahsasni S, Kouhila M, Mahrouz M, Idlimam A and Jamali A. (2004) Thin layer convective solar drying and mathematical modelling of prickly pear peel (Opuntia ficus indica). Energy, 29: 211-224

Luna D, Nadeau JP and Jannot Y. (2009) Solar timber kilns: state of the art and foreseeable developments. Renewable and Sustainable Energy Reviews, 13:1446-1455

Madhlopa A and Ngwalo G. (2007) Solar dryer with thermal storage and biomass-backup heater. Solar Energy, 81: 449-462.

Mahmouda KG and Ball HD. (1991) Solar desiccant systems for grain drying. Energy Conversion and Management, 31: 595-598.

Midilli A and Kucuk H. (2003) Mathematical modelling of thin layer drying of pistachio by using solar energy. Energy Conversion and Management, 44: 1111-1122.

Muller J, Reisinger G, Kisgeci J, Kotta E, Tesic M and Muhlbauer W. (1989) Development of a greenhousetype solar dryer for medicinal plants and herbs. Solar Wind Technology, 6: 523-530.

Mumba J. (1996) Design and development of a solar grain dryer incorporating photovoltaic powered air circulation. Energy Conversion and Management, 37: 615-621. 
Munira A. Sultan, U and lqbal M (2013) Development and performance evaluation of a locally fabricated portable solar tunnel dryer for drying of fruits, vegetables and medicinal plants, Pakistan Journal of Agricultural Sciences, 50, 493-498.

Narinesingh, D., and Mohammed-Maraj, R., (1988) Solar Drying Characteristics of Papaya (Carica papaya) Latex, Journal of the Science of Food and Agriculture, 46: 175-186.

Olufayo AA, and Ogunkunle OJ. (1996) Natural drying of cassava chips in the humid zone of Nigeria. Bioresourses Technology, 58: 89-91.

Onyegegbu SO, Morhenne J and Norton B. (1994) Second law optimisation of integral type natural circulation solar energy crop dryers. Energy Conversion and Management, 35: 973-983.

Pangavhane DR and Sawhney RL. (2002) Review of research and development work on solar dryers for grape drying. Energy Conversion and Management, 43: 45-61.

Patil BG and Ward GT. (1989) Simulation of solar air drying of rapeseed. Solar Energy, 43:305-320.

Phillips AL. (1965) Drying coffee with solar-heated air. Solar Energy, 9: 213-216.

Prasad J, Vijay VK, Tiwari GN and Sorayan VPS. (2006) Study on performance evaluation of hybrid drier for turmeric (Curcuma longa L.) drying at village scale. J Food Engineering, 75: 497-502.

Punlek C, Pairintra R, Chindaraksa S, and Maneewan S. (2009) Simulation design and evaluation of hybrid PV/T assisted desiccant integrated HA-IR drying system (HPIRD). Food Bio Process, 87: 77-86.

Radajewski W, Jolly P and Abawi GY. (1987) Optimisation of solar grain drying in a continuous flow dryer. J Agricultural Engineering Research, 38: 127-144.

Ramana Murthy MV. (2009) A review of new technologies, models and experimental investigations of solar driers. Renewable and Sustainable Energy Reviews, 13: 835-844.

Roa G and Macedo IC. (1976) Grain drying in stationary bins with solar heated air. Solar Energy, 18: 445449.

Roman F, Nagle M, Leis H, Janjai S, Mahayothee B, Haewsungcharoen M. and Muller, J. (2009). Potential of roof-integrated solar collectors for preheating air at drying facilities in Northern Thailand. Renewable Energy, 34: 1661-1667.

Sacilik K, Keskin R and Elicin AK. (2006) Mathematical modelling of solar tunnel drying of thin layer organic tomato. J Food Engineering, 73: 231-238. 
Sacilik K. (2007) Effect of drying methods on thin-layer drying characteristics of hull-less seed pumpkin (Cucurbita pepo L.). J Food Engineering, 79: 23-30.

Sarsilmaz C, Yildiz C, and Pehlivan D. (2000) Drying of apricots in a rotary column cylindrical dryer (RCCD) supported with solar energy. Renewable Energy, 21:117-127

Schirmer, P., Janjai, S., Esper, A., Smitabhindu, R., and Mühlbauer, W., (1996) Experimental Investigation of the Performance of the Solar Tunnel Dryer for Drying Bananas, Renewable Energy, 7: 119-129.

Sharma A, Chen CR, and Lan NV. (2009) Solar energy drying systems: a review. Renewable and Sustainable Energy Reviews, 13: 1185-1210.

Sharma VK, Colangelo A, and Spagna G. (1992) Investigation of an indirect type multi-shelf solar fruit and vegetable dryer. Renewable Energy 2: 577-586.

Sharma S, Sharma VK, Jha R, and Ray RA. (1990) Evaluation of the performance of a cabinet type solar dryer. Energy Conversion and Management. 30: 75-80.

Singh S, Singh PP, and Dhaliwal SS. (2004) Multi-shelf portable solar dryer. Renewable Energy, 29: 753-765.

Singh PP, Singh S, and Dhaliwal SS. (2006) Multi-shelf domestic solar dryer. Energy Conversion and Management, 47:1799-815.

Smitabhindu R, Janjai S and Chankong V. (2008) Optimisation of a solar-assisted drying system for drying bananas. Renewable Energy, 33: 1523-1531.

Sodha MS, and Chandra R. (1994) Solar drying systems and their testing procedures: a review. Energy Conversion and Management, 35: 219-267

Sreekumar A, Manikantan PE, and Vijayakumar KP. (2008) Performance of indirect solar cabinet dryer. Energy Conversion and Management, 49:1388-95.

Tarhan S. (2007) Selection of chemical and thermal pretreatment combination for plum drying at low and moderate drying air temperatures. J Food Engineering, 79: 255-260.

Tayeb AM. (1986) Modern solar grain dryer. Solar Wind Technology, 13: 211-214.

Taylor KJ and Weir AD. (1985) Simulation of a solar timber drier. Solar Energy, 34,249-255.

Thoruwa TFN, Smith JE, Grant AD and Johnstone CM. (1996) Developments in solar drying using forced ventilation and solar regenerated desiccant materials. Renewable Energy, 9, 686-689. 
Thoruwa TFN, Johnstone CM, Grant AD and Smith JE. (1996) Novel, low cost $\mathrm{CaCl}_{2}$ based desiccants for solar crop drying applications. Renewable Energy, 9, 686-689.

Tiwari GN, Singh AK, and Bhatia PS. (1994) Experimental simulation of a grain drying system. Energy Conversion and Management, 35: 453-458.

Togrul IT, and Pehlivan D. (2002) Mathematical modelling of solar drying of apricots in thin layers. J Food Engineering, 55: 209-216.

Tomar V, Tiwari G.N. and Norton B (2017) Thermophysics of crops, systems and components of solar dryers for tropical food preservation Solar Energy, In Press

Tron D.S. and Ko M.Y. (1982) Development of a forced convection solar dyes for red peppers, Tropical Agriculture (Trinidad), 59, 319-323.

Tripathy PP, and Kumar S. (2009) A methodology for determination of temperature dependent mass transfer coefficients from drying kinetics: application to solar drying. J Food Engineering, 90: 212-218.

Venkataraman S. V., Iniyan S. and Goic R. (2012) A review of solar drying technologies, Renewable and Sustainable Energy Reviews, 16. 2652-2670.

Williamson, J, Williamson, T. and Callahan C (2008) Solar Seed Dryer and Storage Bin at State Line Farm, Bennington, VT; Feasibility Analysis, Callahan Engineering, Cambridge, New York, 12816, USA.

Yaldiz O, Ertekin C and Uzun HI. (2001) Mathematical modelling of thin layer solar drying of sultana grapes. Energy, 26: 457-65

Zaman MA and Bala BK. (1989) Thin layer solar drying of rough rice. Solar Energy, 42:167-171. 